\title{
БЕЗСПОЛУЧНИКОВІСТЬ ЯК ЗАСІБ УВИРАЗНЕННЯ МОВЛЕННЯ МАС-МЕДІА
}

Мелкумова Т. В. Безсполучниковість як засіб увиразнення мовлення мас-медіа.

У статті з'ясовуються комунікативно-прагматичні функції безсполучниковості. Особливості використання асиндетону досліджуються на матеріалі інформаційного та публіцистичного мовлення. Безсполучниковість розглядається як стилістична фігура, заснована на пропускові сполучних засобів між компонентами речення. Дослідження стилістичних фігур у мовленні сучасних мас-медіа відкриває перспективи в поглибленні знань про тексти різного функційного призначення.

Ключові слова: безсполучниковість, асиндетон, комунікативно-прагматична функція, виражальний засіб, мас-медійне мовлення.

Мелкумова Т. В. Бессоюзие как средство усиления выразительности речи масс-медиа.

В статье выясняются коммуникативно-прагматические функции бессоюзия. Особенности использования асиндетона исследуются на материале информационной 
и публицистической речи. Бессоюзие рассматривается как стилистическая фигура, основанная на пропуске соединительных средств между компонентами предложения. Исследование стилистических фигур в речи современных масс-медиа открывает перспективы в углублении знаний о текстах разного функционального назначения.

Ключевые слова: бессоюзие, асиндетон, коммуникативно-прагматическая функция, выразительное средство, масс-медийная речь.

Melkumova T. W. Asyndetically structure as a mean of strengthening expressive speech of media.

Today the role of mass media is increasing in modern society. The linguists broadly explore instruments of influence and strengthening expressive speech of media. The actual problems of modern linguistics are peculiarities of use and functions of expression syntax means. The article investigates the communicative pragmatic function of asyndetically structures. The features of asydeton using are studied in the information and journalistic speech. Asydeton is seen as a stylistic figure, based on the pass connecting means between the components of the sentence or text. The asyndetic connection between parts of a sentence is based on the semantic filling of parts of speech, which are incorporated in complex sentences and form semantic and intonation unity. In speech, this relationship is expressed by rhythmic and melodic means, in writing - punctuation. The emission of a conjunction of the parts before each sentence has a definite meaning and intonation shade throughout statement. The reduction syntactic structure, including asyndetically structure, promotes statements of pragmatic communicative functions: representative, declarative, affirmative, expressive, appellative and more. The interaction among asyndeton with other stylistic figures allows the speaker to single out the important piece of information, enhance the expression of certain components, provide the dynamism of speech and so on. The elucidation of the interaction means of expression syntax and pragmatic functions within a mass-media text is important for its understanding of the production and perception. Sometimes expressiveness is achieved by the combination asyndetic and complex conjunctive connection: complex conjunctive structure creates a slow pace, which shows especial contrast in impression of asyndeton. The asyndeton implements the information texts more than commentary. This is due to various pragmatic purpose of these kinds of texts. The research stylistic figures in modern media speech offers the prospect of a deepening knowledge of the texts of various functional purpose.

Key words: asyndetically structure, asyndeton, communicative pragmatic function, expression mean, mass media speech.

3 огляду на зростання ролі мас-медіа в житті сучасного суспільства мовознавці широко досліджують посилення виразності мовлення засобів масової інформації. Сучасна лінгвістика приділяє багато уваги вивченню функцій $\mathrm{i}$ особливостей уживання виражальних засобів синтаксису; найбільш частотними з них у медіатекстах є повтор, парцеляція, риторичне питання. Асиндетон, якщо й не знаходиться на периферії мовознавчих зацікавлень (як плока), тим не менш належить до рідко досліджуваних явищ синтаксичної ( Т. В. Мелкумова, 2016. $-226-$ 
стилістики (на матеріалі мас-медійних текстів), що й зумовлює актуальність теми нашої розвідки.

Словники розтлумачують дефініцію «асиндетон» так: «безсполучниковий зв'язок» [1, с. 57]; «будова переважно поетичного мовлення, з якого усунені сполучники задля увиразнення та стислості виразу» $[5$, с. 66]. Спільної думки дотримуються лінгвісти здебільшого при визначенні безсполучниковості як фігури та при окресленні їі стилістичних функцій [2, с. 308; 4, с. 229]. О. Пономарів зазначає, що безсполучниковий виклад сприяє стислості мовлення, надає йому виразності й стрімкості $[6, \quad$ с. 241]. «Явище безсполучниковості стилістично вмотивоване, - стверджує В. Ващенко. - Як контраст до сполучникових конструкцій, асиндетичні речення виступають у мовленні досить виразним стилістичним засобом. Дають можливість повніше й яскравіше зафіксувати деякі вузлові моменти вислову, підкреслити й увиразнити якісь відтінки, зміцнити їх стилістичну вагу» [3, с. 35].

Метою статті є визначити комунікативно-прагматичні функції безсполучниковості в мас-медійних текстах. Джерельною базою послужили матеріали радіопередачі «Новини» Національної радіокомпанії України; мережевого інформаційного агентства «Новини» Львівської обласної державної адміністрації; інформаційної телепередачі «Факти» (ICTV); телепрограм «Дуель» (ТРК «Україна»), «Свобода слова» (ICTV), «Я так думаю» («1+1»), «Шустер live» (ТРК «Україна»); газет «Вісті Придніпров'я», «День», «Україна молода», «Українське слово»; журналу «Сучасність».

Безсполучниковість може сприяти реалізації власне репрезентативної (номінативної) функції: Але нам не кажуть, щуо в пожежі треба знайти винних, допомогти людям, ліквідувати наслідки. Нам кажуть: «Давайте вибори» [ЯТД, 17.04.2008]; Ви обічяли, вони теж обіияють [Д, 22.11.2007]. Окрім повідомлення, наведені тексти передають емоції, зокрема обурення. Зауважимо, що ступінь виразності асиндетичних конструкцій бінарного типу залежить від їхньої лаконічності: виразнішими є більш лаконічні висловлювання. Асиндетон інтенсифікує власне репрезентативну функцію і в таких контекстах: Чудово працював на тому заводi. Провів інвестиції, заробітна плата, нові люди зберуться на роботу, нормально все. Беруть, відбирають в нього, повертають до 
держави [ШL, 18.06.2010]; Аргументація «проти» з їх боку була такою - Польщча втратить свої традищї, історію, мову [ВП, 27.11.2003]. Опис аргументів завдяки безсполучниковості лаконічний, стрімкий, позиція автора завуальована.

Безсполучниковість інформаційного тексту конденсує подачу інформації: Вже встановлено два ряди пам'ятників, взялися за третій [Дн, 15.12.2015]; Двоє військовослужбовців добровольчого батальйону загинули під час обстрілу автобуса на блокпості в Донецькій області 13 серпня, третій солдат загинув у Старобешівському районі Донецької області в кінці липня [Дн, 25.09.2014]; Сам Джуліан Ассандж нині перебуває на території Великобританії, вивчається питання його екстрадииї до Швеції [НРКУ, 24.12.2010]. Відсутність сполучників надає висловленню конденсованості змісту.

Асиндетон інтенсифікує експозитивну функцію (підстави й аргументи повідомлень) у мас-медійних текстах: ...число вже ввійшло в украӥнську історію: дванадиять мільйонів чотириста вісімдесят одна тисяча двісті шістдесят шість - кількість голосів за четвертого Президента [Ст, 2010, № 5, с. 164]. Екскурс у історію здійснено з використанням безсполучниковості. Саме асиндетичний зв'язок є тут засобом створення фотографічної точності опису, також допомагає виявити авторське ставлення до зображуваного, посилюючи тим самим комунікативно-прагматичний вплив тексту.

Конденсація думки, що досягається завдяки безсполучниковості, виразно експлікує пояснювальне значення речення: Наскільки одновимірною була сила «правильна» (православ'я - Росія - мир єдність - прочвітання), настільки ж багатоплановою, однак у всіх своїх площинах загрозливою видавалася сила протилежна (Захід Україна - війна - розкол - занепад) [Ст, 2007, № 10, с. 77]; Така готовність закривати очі пояснюється тим, щзо изі люди вважають, санкції не працюють («не змінилися поведінку Росї̈), вони бояться подальших втрат бізнесу, думають у дуже коротких циклах, таємно захоплюються Путіним (Орбан), обурюються німецьким лідерством [Дн, 11.12.2015].

Безсполучниковість може посилювати декларативність (сповіщальна функція): I якщо прогнозувати можливий сценарій розвитку подій, то він розгорнеться в такій послідовності:

С Т. В. Мелкумова, 2016. 
ослаблення зв'язків між різними групами - маючи «благословення» Леоніда Кучми, СДПУ(о) переконує різними способами депутатів погодитися на ї̈ сценарій - відбувається зміна декорачій [УС, 04.12.-10.12.2003]. Завдяки асиндетону мовлення стає лаконічним, покликане збуджувати в уяві адресата чітку зміну подій, які мовець робить спробу передбачити. Асиндетичний зв'язок між компонентами конденсує інформацію, сприяє лаконічності повідомлення: Нині пам'ятка перебуває у незадовільному стані необхідно провести термінові протиаварійні та ремонтнореставрачійні роботи [ЛОДА, 24.12.2010].

Для публіцистичного мовлення стверджувальної настанови характерна взаємодія стилістичних фігур. Так, сприяти експлікації репрезентативної прагматичної мети «ствердження» може антитеза в поєднанні з безсполучниковістю: Справді: на одному кіниі Хрещатика - Ленін, на іншому - монумент Незалежності [Ст, 2001, № 10, с. 73]. Виразно інтенсифікує стверджувальну функцію еліпсис: $A$ зашморг був, усі його бачили і всі відчували [Ст, 2010, № 5, с. 165]. У цьому реченні прагматична мета досягається й за допомогою висхідної градації та синтаксичного паралелізму (друга й третя предикативні частини). Реалізації функції ствердження слугує і асиндетон: Більші громі - краща армія - відповідь сусідів. I ияя спираль розвивається у Європі аж до ХХ сторіччя [Ст, 2010, № 5, с. 188].

Безсполучниковість може сприяти виконанню висловлюванням: 1) експресивної функції: Крок у крок, лоб у лоб [УМ, 02.11.2004] безсполучниковість і паралельна побудова предикативних частин наведеного складного речення сприяють увиразненому зображенню наполегливості та невідступності в намірах певних осіб; 2) апелятивної функції (звернення до реципієнтів): $B$ прокуратуру, 8 СБУ? Куди, коли всі одна влада? [ШL, 19.12.2008]; 3) волюнтативної функції (функції впливу): Звернімо увагу: високі мусульманські достойники слушно наголошують, що іслам не схвалює вбивства людей [Ст, 2001, № 12, с. 72]; Всім нагадую Будапештський меморандум, почитайте його [ЯТД, 08.06.2005] - асиндетон надає викладу динамічності, допомагає мовцю сконденсовано висловити думку, звернутися до читачів/ слухачів із певними пропозиціями (Звернімо увагу; Почитайте).

Отже, безсполучниковість, функціонуючи в мас-медійному 
мовленні, інтенсифікує його комунікативно-прагматичний вплив експресивність, комісивність, волюнтативність, репрезентативність тощо. Узаємодія асиндетону 3 іншими засобами (зокрема 3 паралелізмом, ампліфікацією, анафорою та ін.) дозволяє мовцю виокремити важливу частину інформації, підсилити певні компоненти висловлення, надає тексту динамізму. Загалом дослідження стилістичних фігур у мовленні сучасних мас-медіа відкриває перспективи в поглибленні знань про тексти різного функційного призначення.

\section{Література}

1. Ахманова О. С. Словарь лингвистических терминов / О. С. Ахманова. [4-е изд., стереотип.]. - М. : КомКнига, 2007. - 576 с.

2. Брандес М. П. Стилистика текста. Теоретический курс : учебник / М. П. Брандес. - [3-е изд., перераб. и доп.]. - М. : Прогресс-Традиция ; ИНФРА-М, 2004. $-416 \mathrm{c}$.

3. Ващенко В. С. Стилістика речення в українській мові : [навчальний посібник] / В. С. Ващенко. - Дніпропетровськ, 1968. - 158 с.

4. Галич О. А. Теорія літератури : [підручник] / О. А. Галич, В. М. Назарець, Є. М. Васильєв ; за наук. ред. О. А. Галича. - К. : Либідь, 2001. -488 с.

5. Літературознавчий словник-довідник : [довідково-енциклопедичне видання] / авт. кол. : О. Астаф'єв, З. Бичко, Б. Бірчак та ін. ; ред. кол. : Р. Гром’як, Ю. Ковалів, В. Теремко. - К. : ВЦ «Академія», 1997. - 752 с.

6. Пономарів О. Д. Стилістика сучасної української мови : [підручник] / О. Д. Пономарів. - [3-тє вид., перероб. і доповн.]. - Тернопіль : Навчальна книга Богдан, 2000. $-248 \mathrm{c}$.

\section{Перелік умовних скорочень}

ВП - «Вісті Придніпров'я», обласна газета

Д - - Дуель», ток-шоу (ТРК «Україна»)

Дн - «День», газета (м. Київ)

ЛОДА - «Новини» Львівської обласної державної адміністрації, мережеве інформаційне агентство

НРКУ - «Новини» (Національна радіокомпанія України)

СC - «Свобода слова», ток-шоу (ICTV)

Ст - «Сучасність», журнал (м. Київ)

УМ - «Україна молода», газета (м. Київ)

УС - «Українське слово», газета (м. Київ)

$\Phi-$ - «Факти», інформаційна телепрограма (ICTV)

ЯТД - «Я так думаю», ток-шоу $(« 1+1 »)$

ШL - «Шустер live», телешоу (ТРК «Україна»)

Стаття надійшла до редакиії 08.11.2015 p. 